\title{
Africa, the Sweet Home of Roots or the Dark Continent of Primitiveness?: Alice Walker's Africa in The Color Purple
}

\author{
Lei $\operatorname{Sun}^{1} \&$ Xiangyong Kong ${ }^{1}$ \\ ${ }^{1}$ Foreign Languages College, Tianjin Normal University, Tianjin, China \\ Correspondence: Lei Sun, Foreign Languages College, Tianjin Normal University, Xiqing District Binshui Rd \\ 373, Tianjin 300387, China. E-mail: sunlei003068@tjnu.edu.cn
}

Received: December 26, 2019 Accepted: January 22, 2020 Online Published: January 31, 2020

doi:10.5539/ells.v10n1p26 URL: https://doi.org/10.5539/ells.v10n1p26

\begin{abstract}
With the detection from the post-colonial perspective, there is a certain amount of truth in the statement that Alice Walker's The Color Purple sometimes reveals Eurocentric ideology, even though she overtly makes efforts for Africa and Africans. The way in which she delineates Nettie's missionary job in Olinka, confirms habitual Western suspicions about equality between Europe and Africa. With the reexamination of the depiction about the African continent Nettie sketches out, additionally, we might notice Walker's intention of setting up Africa as a foil to Europe, to some extent, echoes Said's orientalist discourse.
\end{abstract}

Keywords: post-colonial criticism, eurocentrism, Other, The Color Purple

\section{Introduction}

The epistolary novel The Color Purple won Alice Walker both the American Book Award and the Pulitzer Prize in 1983. For long, it has been regarded as one of Walker's representative works resorting to African ethnic group for cultural expressions, exploring African cultures and traditions. She acclaims to explore the issue of Womanism trying to reassess the world and women with an approach to Africa and Africans, aiming to draw on features of the African world, to reconstruct her vision of the indigenous experience. It seems, in the whole novel, that Alice Walker extolls Africa and Africans, situating herself within textual evidences of Nettie's identification of roots in Africa, the light she casts on African traditions - quilt-making, the Spirit, the yam, the roofleaf, and the blues. However, the novel sometimes reveals a latent sense of Eurocentrism and subtle traces of imperialism and colonialism (Note 1) if we problematize some depictions in the novel, from the post-colonial perspective.

\section{The Missionary Job in Olinka}

In the letters, Nettie depicts the story in which the Reverend Samuel and Corrine, who adopt Celie's children as saviors, practice the holly religion among the Olinka people as representative members of the missionary group, in Walker's eyes, who have been sent to all over the world, impose their divine responsibility on their shoulders to "People who need Christ and good medical advice" (p. 123). Before starting their journey to Africa, Nettie and the Samuels say goodbye to their church group with "such high hopes for what can be done in Africa" (p. 125). Before leaving, the missionary job has engendered a sense of Eurocentric superiority, that is, to light in the "dark" continent. The missionary, to some extent, is portrayed like a savior and a teacher.

Although the missionaries Nettie met in England express their "love" for living in huts and for their open feeling of the village, they send their children back home because "it was no longer possible to teach them in the bush" (p. 152). Even the benevolent missionaries have to confess that there is no civilization in the "bush" regardless of their strong "love" for Africa. It is no doubt that Western missionaries sent to Africa, including Nettie, Samuel and Corrine, have held the European view as the universal one, projecting Western's image of civilized and developed, as opposed to African's image of barbarous and undeveloped. The Africa, through Walker's latent Eurocentric description of the missionary job, is still an uncivilized and primitive child who needs his civilized European mother to nurture him.

What the black missionaries teach the children are not African cultures and languages, but "English, reading, writing, history, geography, arithmetic and the stories of the bible" (p. 144), which represent the developed Western civilization. Actually, Western education in Africa, which is usually carried by the missionary, aims at transforming Africa and imposing Western civilization on this "dark" barbarous land, especially the African 
backward traditions. It seems, then, that Nettie never realizes the way in which they teach Western knowledge to the Olinka children has been a white cultural aggression to Africa. We are liable to get the conclusion that these European curriculums, no doubt, hasten the Olinka children to dislocate from their own ethnic cultural background, if we re-examine them with a post-colonial insight. There are some post-colonial sensibilities in the fact that Nettie and her missionary friends teach English to the Olinka children. "The domination of a people's language by languages of the colonizing nations," as Thiong'o (Note 2) points out, "was crucial to the domination of the mental universe of the colonized." (qut. in Mazrui, p. 161) (Note 2) Thus, English, as the most distinctive European language, plays a crucial role in the colonial attempt to force Africans to accept an inferior situation and lose confidence in their own language and culture. It is no doubt that the teaching of English has molded language into a weapon in their domination of peoples of other cultures. "With words forged like truncheons, Africans have been battered into submission" (Mazrui, p. 167). The operation of teaching English to Olinka children constrains, actually, them to demand an aboriginal language which will allow them to express their sense of "Otherness". When it comes to the fact that they teach history and geography to the children, it is no exaggeration to state that it is an essential post-colonial brainwashing, since the two curriculums, associated with the Eurocentric ideology, are defined and compiled by Westerners. Compared with the image of the undaunted, intelligent Western Columbian pioneers, the non-Western people will be, unconsciously or subconsciously, associated with barbarism and backwardness. For example, in a well-known geography textbook in the Edwardian period, still in print in the 1930s:

The natives of Australia... were among the most miserable men. They roamed nearly naked, and were ignorant of everything except the chase. The explanation of their degraded condition lies in the climate of Australia. Their great poverty led them to practice vices like cannibalism and the murder of the sick and the helpless. (Hebertson, pp. 1-2)

The natives of Australia, from the above quaotation, was distanced to be situated in the position of ignorance, barbarism, and primitiveness. Said once comments the mental operation of imaginary geography in Orientalism: "this universal practice of designating in one's mind a familiar space which is 'ours' and an unfamiliar space beyond 'ours' which is 'theirs' is a way of making geographical distinctions that can be entirely arbitrary" (p. 54). With the "entirely arbitrary", Western history and geography have been operated with the cultural colonization to the colonized. Exhibiting the distinction between "our" land and "their" land through Eurocentric imaginary geography, Europeans are designated to subjugate Africans. The history curriculum can be more imaginative, in terms of Said orientalist discourse, since it centers on the advancement of European's civilization by othering non-Europeans. It is no doubt that, with the teaching geography and history to the Olinka children, they will uphold a Eurocentric concept in history and geography, regardless of their own African ones. Even teaching arithmetic, the generally-defined scientific curriculum, has been endowed with a sense of Eurocentric superiority. Actually, the imperial ideology legitimizes the mathematical development as a purely European product. George Gheverghese Joseph has commented the process of teaching mathematics in his article "Mathematics and Eurocentrism", that "It [The imperial experience] fostered the myth that mathematics was a civilizing gift that Europe brought to the colonies, a Promethean spark that in time would enable the backward natives to penetrate the secrets of science and technology and enter the modern world." (p. 121) Thus, the Eurocentric process of teaching mathematics to the Olinka children, regardless of Olinka's mathematical mode of thinking, is the equivalent of upholding the superiority of the European races and of the colonization in Africa. Even if Nettie and her missionary friends have no intention of colonizing and ruling the Olinka people, their savior-like missionary job functions as an accessary with Western imperialists. When it comes to the "some stories in the Bible" these black missionaries teach to the Olinka's children, Nettie's assertion of being a black missionary differentiating from white missionaries becomes problematic. In the Christian Bible, the story that the white dominating man-like God creates the world, virtually, estranges these African children from their own concept of God and the world. Through teaching other stories of the Bible-Adam and Eve, the sacrifice of Jesus, going down of Mosese, and the like-Nettie and her missionary friends, in fact, undergo a process of latent cultural imperialism. In a word, the Eurocentric ideology, practiced through inculcating "English, reading, writing, history, geography, arithmetic and the stories of the bible" (p. 144), has been a pervasive force in Western-established schools. With the course the Olinka children receive, hardly could they resist being in colonized subjugation because they are inculcated to believe in Eurocentric superiority and hence their inferiority. It is no wonder that some young Olinka people try to imitate the whites, acting in the manner of a postcolonial term "mimicry".

Through Nettie, Walker exposes her ambivalence of the benevolent missionary: condemning England for colonizing Africa, while at the same time taking pride in African American missionaries' accessary of 
colonization of the native villages. Samuel's realization of the failure of their missionary job in Africa, also, reinforces Walker's ambivalence of the missionary job in Africa. He complains that "they never even listen to how we've [they've] suffered" (p. 210). Underscoring the sacrificial devotion of Samuel and other missionaries without digging out the reason why "the Africans don't even see us [them]" (p. 210), implies these missionaries' Eurocentric expectation that the missionary job is taken for granted as a charity, which should be warmly welcomed by the local Africans.

Another point worthy to be mentioned is, that the letters from Nettie to her sister are all written in standard British-American English to indicate Nettie is well educated and full of insights as an independent black woman. On the contrary, the letters from Celie are written in the decreasing degree of Black Vernacular English (Note 4), ironically to imply Celie's spiritual transformation from an abused, docile, marginal black woman to an independent, strong-minded one. Anthropologist Conrad Phillip Kottak has pointed out that "it [Black Vernacular English] is a complex linguistic system with its own rules..." (p. 98). However, some Eurocentrists stigmatize BVE as an ungrammatical hodgepodge in which those who speak are often associated with illiterate, backwardness, violence, and little respect. Thus, Nettie is bestowed by Walker, in the initiation story of Celie, with a symbolic significance of an abroad guide directing Celie from the distant African Continent. However, it is noticeable that Nettie with standard British-English outmatches, exactly speaking, dictates her sister with Black Vernacular English to be independent, from the perspective of the languages they adopt. What's more, it is palpable to conclude that Walker attempts to adopt a Eurocentric linguistic strategy in which the process of the abnegation of Black Vernacular English to embrace British-American English indicates Celie's growth from an illiterate, marginalized, abused object to an independent, centered individual. Walker misinterprets Black Vernacular English as sub-standard or incorrect English like whites and some black intellectuals, swamping its "grammatical criteria of a genuine language" (Tyson, p. 384). Hence, Walker virtually, with the linguistic representation of European superiority over Africa, implicates her Eurocentric metropolitan ideology.

\section{Nettie's Eurocentric Depiction of Africa}

Through the letters from Nettie to her sister, she delineates Africa and Africans vividly. However, if we reexamine the depiction about the African continent Nettie sketches out, we might notice it "conjure[s] up neither the texture, the tone, nor the truth of the traditional lives of African people's." (Bell, p. 266) The imperceptible imperial worldview capable of warping the perspectives of readers, distances Walker from her strong adherence to Africa and Africans. Walker's presentation of Africa and Africans, through Nettie's narration, follows that of Western canonical texts where Africa and Africans are stereotyped and twisted as exoticism and barbarism. Thus, "prevalent stereotypical images of Africa in Western popular culture occasionally find their way into Walker's Africa" (Kieti, p. 158).

Exhibiting a sense of nostalgia, Walker delineates Netties' experience of making journey into Olinka with Eurocentric view. With the exotic image of the jungle, she immediately mentions Olinka people's love for meat, which evokes the image of the cannibal Africans lurking around in the jungle to readers subconsciously. The stereotypical images of African people seem to echo those of Western canonical texts where Africans are portrayed as idle, lazy, and rude. The boatmen Nettie and her missionary friends encounter "paid very little attention to us [them] or our [their] cargo" and they "didn't bother to help us [them] alight from the boat and actually set some of our [their] supplies right down in the water" (p. 139). It is no doubt that Walker's depiction of African natives' idleness, laziness and rudeness indicates her Eurocentric ideology.

Nettie writes her sister many letters from the "dark" continent. "We celebrate [Christmas] here on the dark continent with prayer and song and a large picnic." (p. 154) "Darkness" envisioned by Nettie, distances Walker from her ancestry Africa, implicating she had adopted the basic assumptions of the Western canonical text. Compared with the West, Africa is identified with the marginal and the barbarous, which has been oppressed or ignored by Eurocentric, male-dominated history. Christmas, which is a distinctive Christian holiday in Western countries, symbolizes, to some extent, the Western culture and civilization. Although Nettie distinguishes them from white missionaries, she intends to impose the Western civilization on this "dark" barbarous land. Walker's depiction of the "darkness" in Africa, reveals her metropolitan notions about bringing civilization to primitive or barbaric people. Imposing Christmas on Africa, as one of the Western cultures, virtually functions European imperialization in Africa, through Walker's power to narrate Africa and Africans. From this point, Walker situates herself in the metropolitan setting, which bestows her with the power to narrate a textual evidence differentiating Nettie and her missionary friends from Africans. Within such "Darkness", she creates a precise intellectual and historical dimension with which to prop the myth of African geographic distance from Europe.

When Nettie and her missionary friends arrive at the port, she is impressed by the porters' "the strongest, 
cleanest, whitest teeth" (p. 139). The "formed, straight, and strong" teeth, however, evoke the image of horse's teeth from Nettie's eyes. In Said's orientalist discourse, "...the 'savage' is perceived as possessing a 'primitive' beauty or nobility born of a closeness to nature" (Tyson, p. 366). The straight and strong teeth, from Walker's standpoint, somehow identify with those of wild natural animals. The affiliation of the healthy teeth from Africans to horses indicates, to some extent, Walker's latent Eurocentric derogatory views on the Africans. Through Nettie's narration, Walker portrays native Africans in the exotic way.

Walker, through Nettie's depiction of sisterhood among Olinka's women, exposes her confusion towards the female bond, which is one of the African features in Olinka. "It is confusing, I [Nettie] suppose. And it is Samuel's duty as a Christian minister to preach the bible's directive of one husband and one wife" (p. 153). Confused with the observation that "many of the women rarely spend time with their husbands" (p. 153), Nettie and Samuel have never attempted to understand Olinka people's concepts of love, marriage, and sexuality. Anthropologist Conrad Phillip Kottak notes that different marriage systems-monogamy, polygyny, polyandry-seem to be cultural and economical adaptations to distinctive areas (p. 269). Thus, different marriage systems are effective strategies, ensuring the family stability associated with gender-based division of labor. However, Nettie and Samuel tend to analyze Africa from their metropolitan views, sweeping aside the culture, custom and religion of "other". In the Christian Bible, the fact that God made Adam and Eve to be a couple - the monogamous marriage system - has been rooted in every occidental mind. Nettie and Samuel who hold the universal monogamous marriage system, prejudice against Olinka's polygynous marriage pattern. Then, the sisterhood among Olinka's women, which indicates African women's survival strategy as another way of living compared with the Europeans, is portrayed a little bit queerly with the implication that the Olinka's women are still primitive and backward with the unawareness of the patriarchal oppression in the village.

Hence, the exotic depictions of Africa's jungle and its idle and lazy natives, of the "darkness" in the African continent, of the natives' horse-like teeth, and of the "confusing" female relationship in Olinka, somewhat remind us of the descriptions in Joseph Conrad's Heart of Darkness, which, according to Chinua Achebe (Note 5), "projects the image of Africa as 'the other world', the antithesis of Europe and therefore of civilization" (p. 114), condemning Africans as savages and cannibals. For Marlow as much as for Kurtz, Africa and Africans are mostly objects and marginal-Marlow refers to his helmsman as a piece of machinery, and Kurtz's African mistress is portrayed as a piece of statuary. Africa and African natives, for Marlow, just play a role as a mere backward and savage backdrop against which he can attempt his philosophical and existential struggles. Their existence and their exoticism enable his self-contemplation. The fact that Marlow's depiction of Africa and Africans finds echoes in Nettie's, implicates that the Eurocentric ideology of both "white" Conrad's and "black" Walker's has been internalized by the European's colonial domination. In Heart of Darkness, before Kurtz dies, he entrusts Marlow with a packet of personal documents, including an eloquent pamphlet on civilizing the savages which ends with a scrawled message that says, "Exterminate all the brutes!" (Conrad, p. 78) Kurtz's strong determination of colonizing the "barbarous" African natives finds an echo in Nettie's and her missionary friends' decision to civilize the "people who need Christ and good medical advice" (p. 123). Like Malow's ambition that "real work is done there" (Conrad, p. 38) to implicate that he intends to do salvation to African natives, Celie and her missionary friends hold Christian missionary ambition that "such high hopes for what can be done in Africa" (p. 125) assumed before they leave England for Africa, to impose Western "civilized" religion, culture and commerce on them. Exhibiting such great zeal of doing salvation to Africans, Conrad and Walker virtually construct European civilization superior to African's. They both produce a positive national self-definition for Western countries by contrast with African countries upon which the West projects all the negative characteristics.

\section{Conclusion}

The hypostasis of Nettie and her missionary friends' job and Nettie's barbarous and exotic depictions of Africa, all problematize her assertion of embracing Africa and Africans, with recontextualization that the novel is implicated with the issue of imperialism. Edward Said strongly believes that authors "...in the history of their societies, shaping and shaped by that history and their social experience in different measures" (Culture and Imperialism: Introduction, 2002, p. 651). Through the imprintings of white America, African American writers are embedded with their unconscious intention of approaching Eurocentric ideology to be accepted, to approach American white majority with which to be identified. Due to the great influence from the white mainstream culture, Alice Walker has been rooted the Western ideology in her mind subconsciously or unconsciously, bearing a mark of cultural hybridity. She manifests her ambivalence towards her distant ancestral homeland, wavering between her conscious efforts of Afrocentrism and unconscious revelations of Eurocentrism. Vacillating between acceptance and rejection of her ancestry land Africa, Walker's ambivalence affirms the 
complexity of her self-identification.

\section{Acknowledgments}

This work was supported by The Post-Funded Projects of the National Social Science Foundation of China [grant number 18FGJ002]; by The Tianjin Municipal Social Science Foundation [grant number TJJX18-011].

\section{References}

Achebe, C. (1997). An Image of Africa: Racism in Conrad's Heart of Darkness. In W. Maley, B. Moore-Gilbert, \& G. Stanton (Eds.), Postcolonial Criticism (pp. 112-125). London: Longman.

Bell, B. W. (1989). The Afro-American Novel and Its Tradition. Amherst, MA: U of Massachusetts P.

Conrad, J. (1999). Heart of Darkness and other Stories. 1995. Hertforshire: Wordsworth.

Kieti, M. (1996). Homesick and Eurocentric? In F. Ojo-Ade (Ed.), Alice Walker's Africa. Of Dreams Deferred, Dead or Alive: African Perspectives on African-American Writers (pp. 157-170). Westport, CT: Greenwood Press.

Kottak, C. P. (2000). Cultural Anthopology (Ed. Phillip A. Butcher. 8th ed.). Boston: McGraw-Hill.

Mazrui, A. (1995). African Languages and European Linguistic Imperialism. In Enduring Western Civilization: The Construction of the Concept of Western Civilization and Its "Others" (pp. 161-174). Westport, CT: Praeger.

Said, E. (1978). Orientalism. London and Henley: Routledge and Kegan Paul.

Said, E. (2002). Culture and Imperialism: Introduction. In Z. Zhang (Ed.), Selective Readings in $20^{\text {th }}$ Century Western Critical Theory (pp. 637-658). Wang Pengzheng. Beijing: Foreign Language Teaching and Research P.

Tyson, L. (1999). Postcolonial and African American Criticism. Critical Theory Today: A User-Friendly Guide (pp. 363-418). New York and London: Garland Publishing.

Walker, A. (1983a). The Color Purple. New York: Harcourt, Brace, Jovanovich.

Walker, A. (1983b). In Search of our Mothers' Gardens. San Diego: New York; London: Harcourt, Brace, Jovanovich.

\section{Notes}

Note 1 The concept of colonialism refers to the extension of territorial control by establishing colonies, while imperialism refers to a system of forming an empire through many means, like the military control, the control of world markets, and colonization. But as Tyson notes that "today, the words imperialism and colonialism are often used interchangeablely" (Tyson, p. 420).

Note 2. Ngugi wa Thiong'o, a Kenyan writer, writes in his own local language, aiming to reject colonialist ideology and to embrace his pre-colonial indigenous culture. However, those indigenous authors, like Ngugi wa Thiong'o, who write in their native language, face the difficulty in the publishing industry. It needs native writers to make the double effort of writing in their indigenous languages and then having their work translated or translating them into English.

Note 3. Quoted in "African Languages and European Linguistic Imperialism" of Enduring Western Civilization: The Construction of the Concept of Western Civilization and Its "Others" by Alamin Mazrui. He cites Ngugi wa Thiong'o's comment on language and colonization to initiate his article concerning language and decolonization in African countries.

Alamin Mazrui, “African Languages and European Linguistic Imperialism” Enduring Western Civilization: The Construction of the Concept of Western Civilization and Its "Others (Westport, CT: Praeger, 1995, p. 161); Ngugi wa Thiong'o,. Decolonizing the Mind. The Politics of Language in African Literature. (London: Heinemann, 1986, p. 16).

Note 4. Abbreviated as BVE, also called Ebonics (from "ebony" and "phonics") or Black English.

Note 5. He is a Nigerian writer, author of Things Fall Apart, working in postcolonial literary study. He first published "An Image of Africa: Racism in Conrad's Heart of Darkness" in the Massachusetts Review 18: 4 (Winter, 1977). 


\section{Copyrights}

Copyright for this article is retained by the author(s), with first publication rights granted to the journal.

This is an open-access article distributed under the terms and conditions of the Creative Commons Attribution license (http://creativecommons.org/licenses/by/4.0/). 